\title{
ESTUDO DE URBANIZAÇÃO EM ÁREAS DE RISCO A ESCORREGAMENTOS NOS LOTEAMENTOS DO RECREIO SÃO JORGE E NOVO RECREIO, REGIÃO DO CABUÇU, GUARULHOS (SP), BRASIL
}

\author{
STUDY OF URBANIZATION IN AREAS OF LANDSLINE RISK AT THE RECREIO SÃO \\ JORGE AND NOVO RECREIO NEIGHBORHOODS, OF THE CABUÇU REGION, IN THE \\ GUARULHOS TOWNSHIP, STATE OF SÃO PAULO, BRAZIL
}

\section{SATO, Sandra Emi}

Arquiteta e urbanista, mestre em Análise Geoambiental pela Universidade Guarulhos, técnica do Laboratório de Geoprocessamento e professora da Universidade Guarulhos

sandra_arquitetura@yahoo.com.br

\section{OLIVEIRA, Antonio Manoel dos Santos}

Geólogo, doutor em Geografia (USP), coordenador do Laboratório de Geoprocessamento e professor titular do curso de mestrado em Análise Geoambiental da Universidade Guarulhos

aoliveira@prof.ung.br

\section{SAWAYA, Sylvio Barros}

Arquiteto e urbanista, livre-docente (USP) e professor titular da Universidade de São Paulo sbsawaya@usp.br

\section{HERLING, Tereza Beatriz Ribeiro}

Arquiteta e urbanista, doutora em Arquitetura e Urbanismo (USP), coordenadora da Aliança das Cidades e professora da Escola da Cidade

therling@uol.com.br

\section{MORETTI, Ricardo de Sousa}

Engenheiro civil, doutor em Engenharia de Construção Civil e Urbana (USP), professor adjunto da Universidade Federal do ABC

ufabc.moretti@gmail.com

\section{GOMES, Gabriela Lucia da Costa e Castro}

Geógrafa, mestre em Análise Geoambiental (Universidade Guarulhos), professora do Centro Universitário Assumpção (UNIFAl) e da rede pública estadual de ensino de São Paulo gabrielalccastro@yahoo.com.br

\section{RESUMO}

Este artigo, desenvolvido a partir de dissertação de mestrado em Análise Geoambiental da Universidade Guarulhos, apresenta um estudo de urbanização em áreas de risco a escorregamentos dos loteamentos do Recreio São Jorge e Novo Recreio, localizados no município de Guarulhos, São Paulo, Brasil.

estudo adotou a microbacia Taquara do Reino como unidade de planejamento urbano e considerou a carta de zoneamento de risco e suscetibilidade a escorregamentos, assim como a cartografia de restrições legais ao uso do solo. 
O resultado obtido foi a elaboração de uma alternativa de urbanização como ensaio prático de aplicação dos critérios estudados, considerando a necessidade de melhorar-se as condições ambientais do uso do solo nessa microbacia.

Palavras-chave: Urbanização, risco, escorregamento, uso do solo, Guarulhos.

\begin{abstract}
This article, developed at the Master's Program in Geoenvironmental Analysis of the Guarulhos University, presents an urbanization study in areas under landslide risk at the Recreio São Jorge and Novo Recreio neighborhoods, in the city of Guarulhos, State of São Paulo, Brazil. This study adopted the Taquara do Reino watershed as an urban planning unit and considered the zoning map of landslide risk restrictions to land use. This study resulted in the elaboration of an urbanization alternative as a practical test for the studied criteria, considering the need to improve environmental conditions of land use in that watershed.
\end{abstract}

Keywords: Urbanization, risk, landslide, land use, Guarulhos.

\title{
INTRODUÇÃO
}

A área objeto e estudo corresponde à microbacia Taquara do Reino, ocupada pelos loteamentos do Recreio São Jorge e Novo Recreio, na região do Cabuçu, em Guarulhos, São Paulo.

O município possui $341 \mathrm{~km}^{2}$ de extensão territorial, sendo $58 \%$ ocupados por áreas urbanas e $42 \%$ correspondentes à área rural. O município possui, aproximadamente, 1.280.000 habitantes e $95 \%$ ocupam as áreas urbanas (PMG, 2006).

Segundo Andrade (1999), a cobertura florestal em Guarulhos corresponde a 32\% de seu território, recobertos por mata nativa, destacando-se o Núcleo Cabuçu do Parque Estadual da Cantareira.

O Parque Estadual da Cantareira (PEC) é uma unidade de conservação criada pelo Decreto n. 41.626/63. Possui uma área de 7.916 hectares, está localizado nos municípios de São Paulo (54\%), Guarulhos (34\%), Mairiporã (10\%) e Caieiras (2\%) e está dividido em quatro núcleos: Pedra Grande, Engordador, Águas Claras e Cabuçu (HERLING, 2002).

O Núcleo Cabuçu está integralmente situado no município de Guarulhos, possui área de $26,7 \mathrm{~km}^{2}$ e foi objeto de acordo firmado entre o Instituto Florestal (IF), a Secretaria de Meio Ambiente do Município de Guarulhos e o Sistema Autônomo de Água e Esgoto (SAAE) do mesmo município, visando proteger e conservar o Núcleo, para reativar a captação e armazenamento de água do Cabuçu para fins de abastecimento de alguns bairros de Guarulhos.

A área que contorna o Núcleo Cabuçu do PEC foi definida pelo Projeto Cabuçu (OLIVEIRA et al, 2005) como Zona de Defesa (ZD), e delimitada por essa pesquisa em bacias hidrográficas. Atualmente, essa área foi definida pela Lei de Zoneamento de Guarulhos (GUARULHOS, 2007) como APA Cabuçu - Tanque Grande (Figura 1).

A ZD, futura APA, possui aproximadamente $32,2 \mathrm{~km}^{2}$ e envolve áreas de ocupação urbana que correspondem, em sua maioria, a ocupações irregulares, invasões e/ou desmembramentos ilegais de lotes, que exercem pressão sobre esse núcleo (Figura 2). Além disso, dada a reduzida aptidão do meio físico à ocupação urbana, devido ao 
relevo acidentado com altas declividades, suscetibilidade à erosão e movimentos de massa, muitas ocupações são inadequadas geoambientalmente, criando áreas de risco a escorregamentos (OLIVEIRA et al, 2005).

Esse contraste entre ocupação e floresta, bem como o conflito socioambiental representado por essa paisagem, estimulou a elaboração de uma proposta de ocupação urbana mais adequada, favorecendo o meio ambiente tanto da ZD como a preservação do Parque Estadual da Cantareira.

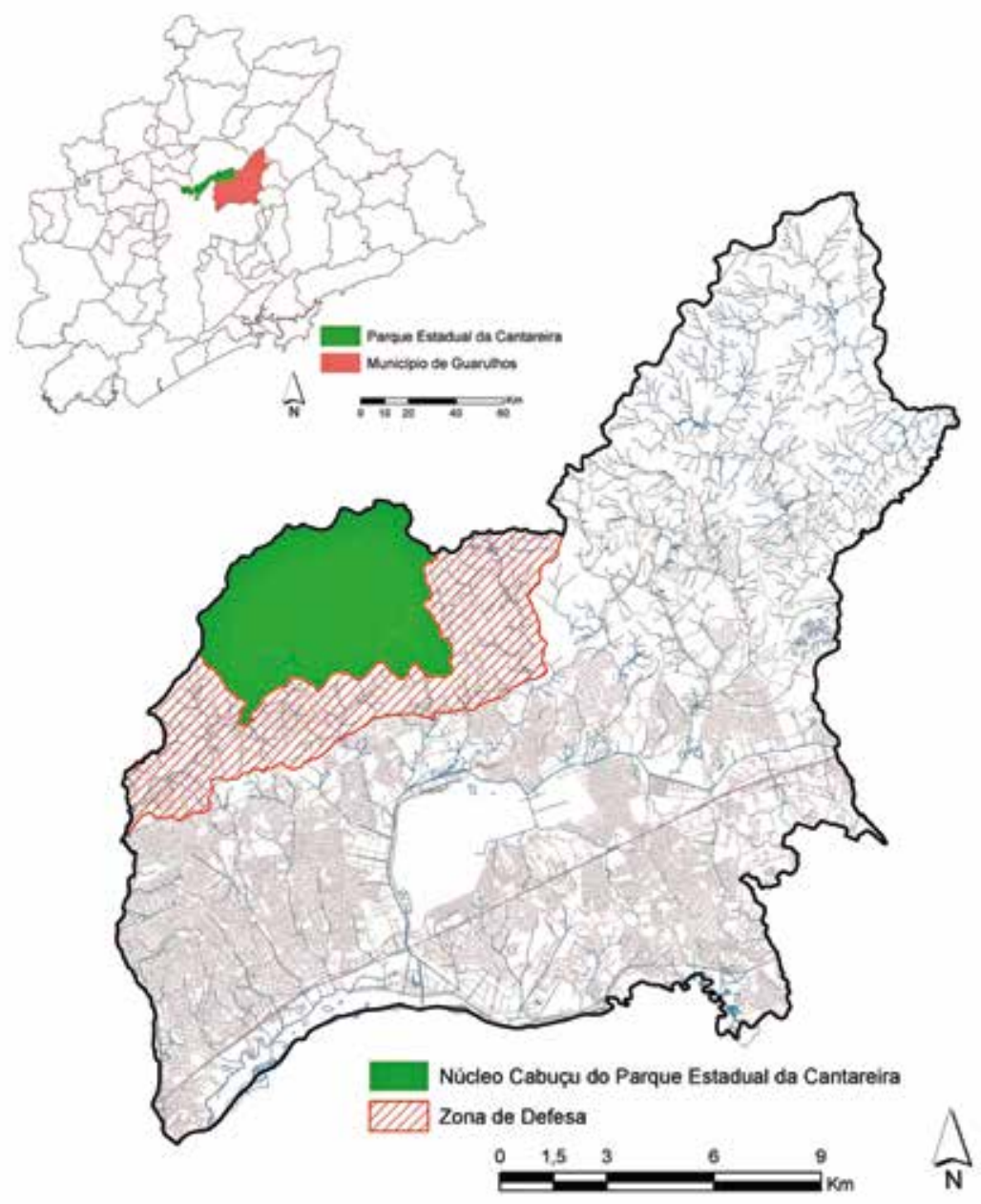

Figura 1: Localização da zona de defesa do Núcleo Cabuçu do Parque Estadual da Cantareira, Guarulhos-SP, em vias de ser a APA Cabuçu - Tanque Grande

Fonte: Oliveira et al

\section{A MICROBACIA TAQUARA DO REINO COMO ÁREA OBJETO DE ESTUDO}

A bacia hidrográfica vem sendo adotada como unidade de gerenciamento, não só de recursos hídricos, mas também como unidade de planejamento do uso do solo 
e de gestão ambiental (TUNDISI, 2003). Ela pode ser considerada um sistema físico, no qual pode ser analisado o balanço hídrico e todos os processos comandados pela dinâmica da água na bacia, como erosão, assoreamento, enchentes, etc., em uma abordagem sistêmica que examina relações de causa-efeito dos processos ambientais do meio físico (QUEIROZ, 2005).

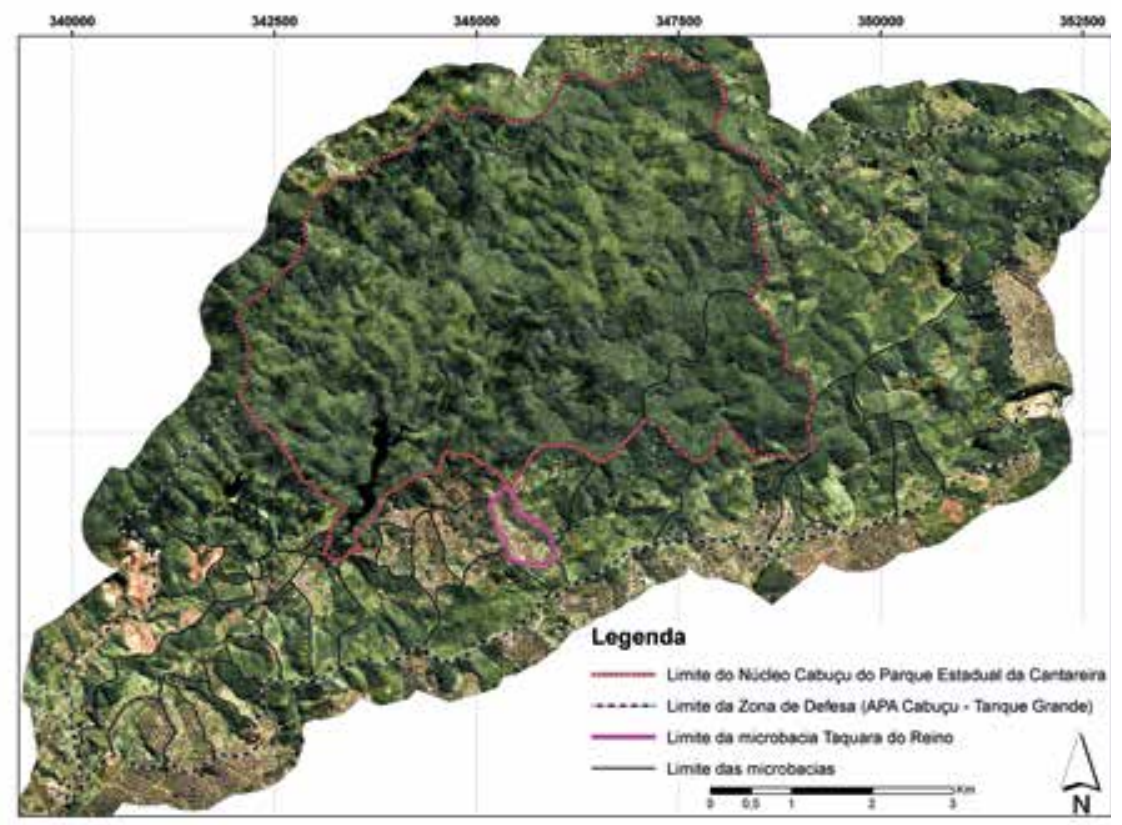

Figura 2: Imagem de satélite QuickBird (2004) da zona de defesa e do Núcleo Cabuçu do Parque Estadual da Cantareira

Fonte: Sandra Emi Sato

As características do meio físico da microbacia são fundamentais, pois geram os condicionantes que direcionam um planejamento urbano e ambiental mais adequado, de maneira a garantir segurança geotécnica e adequação ambiental (FARAH, 2003).

A microbacia objeto deste estudo, Taquara do Reino, com cerca de 5.500 moradores, em uma área total de $42 \mathrm{ha}$, pertence à bacia do Baquirivu Guaçu, afluente do rio Tietê.

A análise da evolução da ocupação urbana da microbacia Taquara do Reino foi realizada por fotos aéreas e imagens de satélite de diversas épocas (Figura 3). Nas fotos aéreas de 1970 e 1988 observa-se que havia somente sítios na microbacia e a maioria das vias existentes se encontravam em topos de morro e permitiam acesso a esses sítios. A mudança significativa aparece na foto aérea de 1993, na qual a ocupação urbana se concentra na vertente direita, por intermédio de loteamento realizado pela Imobiliária Continental. Na foto aérea de 2000 já se observa a ocupação total da microbacia, com loteamentos irregulares de invasões na vertente esquerda e à montante. As imagens de satélite de 2004, 2005 (utilizadas nesta pesquisa) e 2007 apontam o adensamento da região e confirmam a consolidação da ocupação da microbacia Taquara do Reino. 

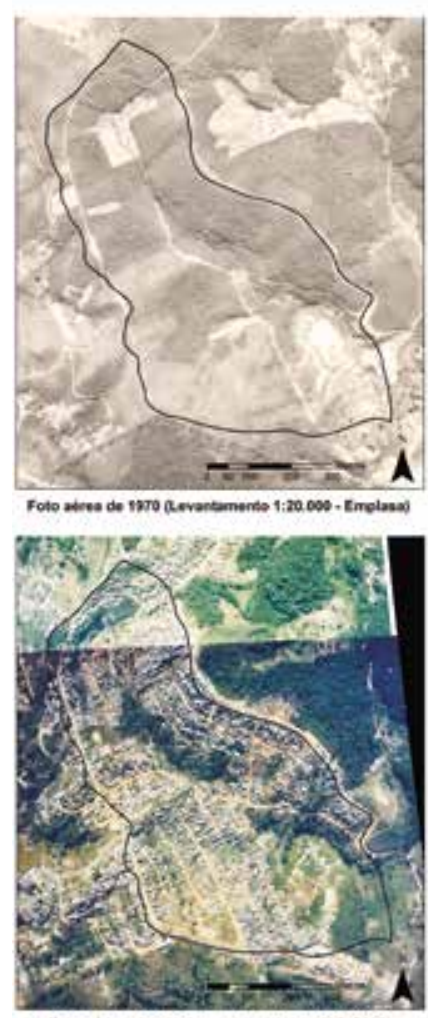

Foto sires de 2006 (Levantamento is 000 .PWO)
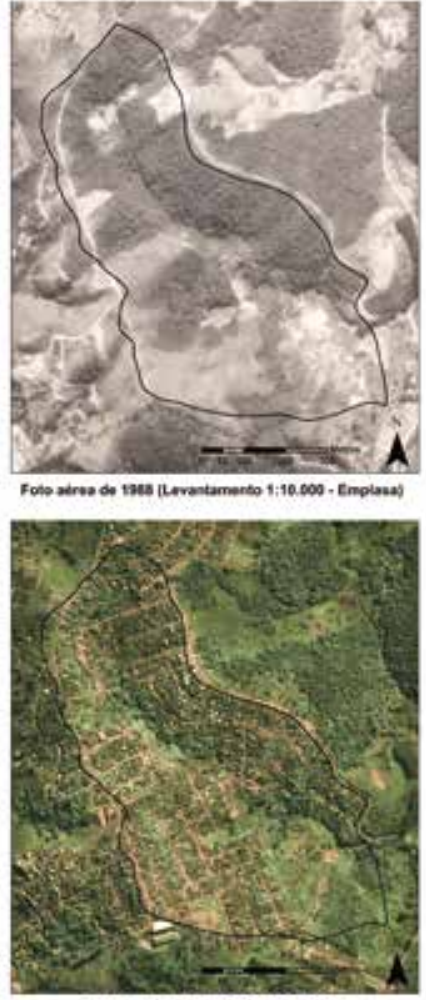

Imapem de sateine Oulchind do 2004
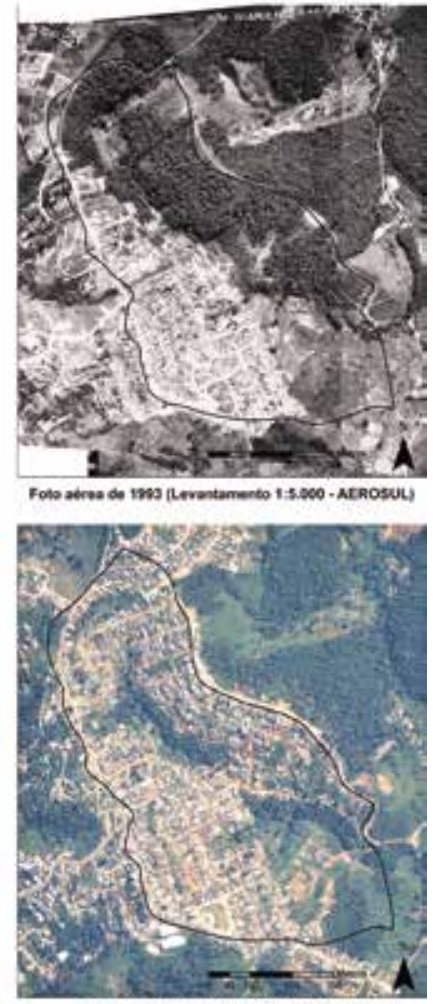

Inapen de sutithe IKONOS de 2007

Figura 3: Evolução da ocupação urbana da microbacia Taquara do Reino Fonte: Sandra Sato, 2008

Com base no mapa de uso do solo de 2004 (Figura 4) verifica-se que ocupação de alta densidade ( $>75 \%$ por quadra), média densidade (25 a 75\% por quadra) e baixa densidade ( $<25 \%$ por quadra) correspondem a $68,5 \%$; as áreas de mata (as copas das árvores tocam-se), capoeira (as copas das árvores estão afastadas entre si), campo antrópico (com poucas árvores ou sem árvores) e reflorestamento possuem 29,5\% e os outros tipos de usos (edificações em chácaras e sítios, grandes galpões e solo exposto) correspondem a $2 \%$. Trata-se, portanto, de uma microbacia intensamente ocupada e com alta densidade de habitações.

A maior parte da área urbanizada não possui regularização na prefeitura e há uma grande mistura de tipos de usos. Os lotes têm dimensão em média de $5 \times 25$ m e a maioria ocupa áreas de risco a escorregamento, condicionados, sobretudo, pela declividade acentuada (GOMES, 2008).

Segundo a Lei n. 6.253/07 (GUARULHOS, 2007), os loteamentos Recreio São Jorge e o Novo Recreio foram definidos como ZEIS L (Zonas Especiais de Interesse Social); assim, correspondem às áreas em que é necessário ordenar as ocupações, pela regularização urbanística e fundiária de assentamentos habitacionais existentes e consolidados, bem como áreas livres nas quais haja interesse social para população de baixa renda. 


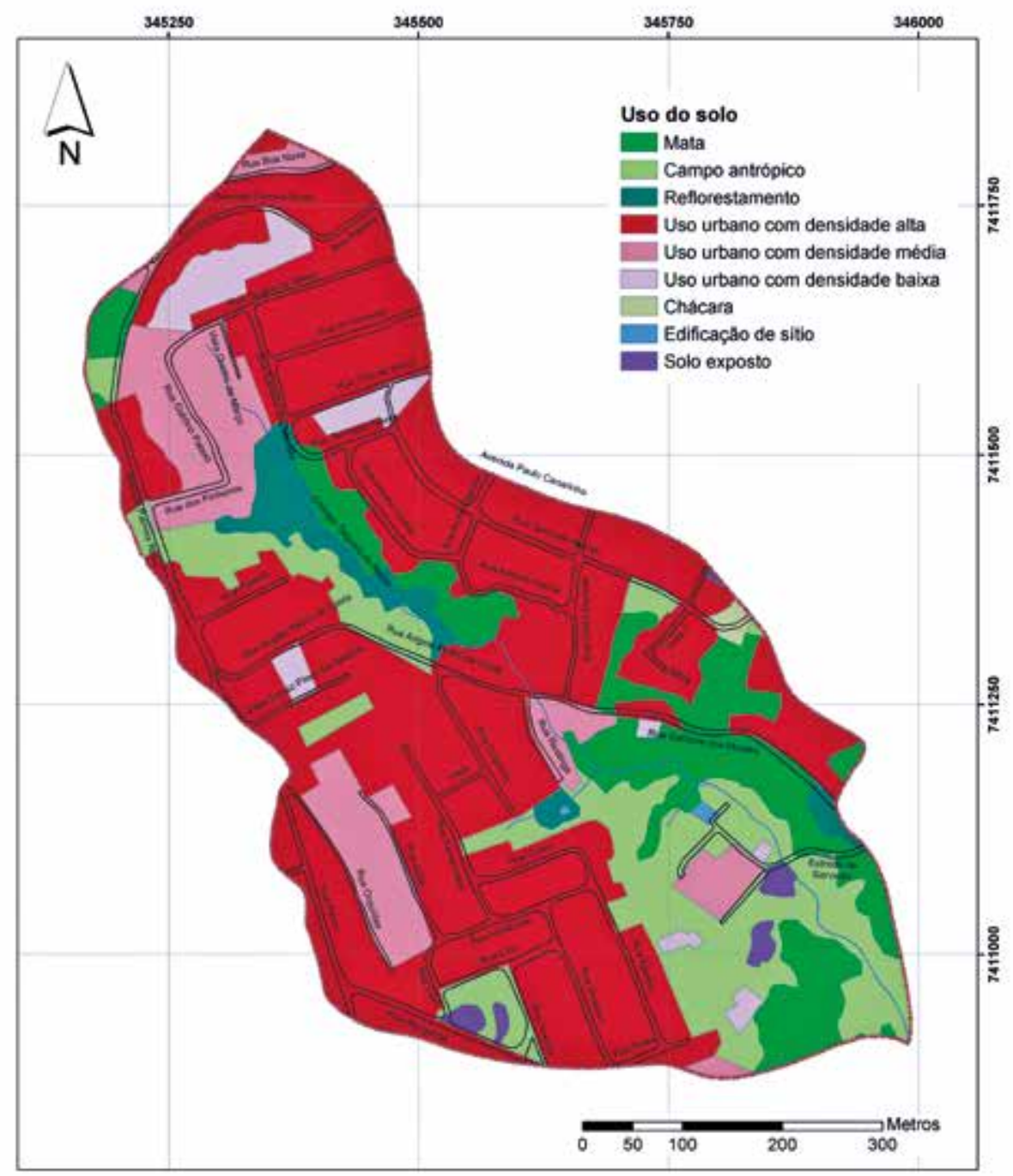

Figura 4: Mapa de uso e ocupação do solo Fonte: Oliveira et al, 2005

\section{OBJETIVOS}

Esta pesquisa teve como objetivo principal realizar um estudo de urbanização, com base em condicionantes geoambientais e na legislação pertinente, dos loteamentos Recreio São Jorge e Novo Recreio, na microbacia Taquara do Reino, município de Guarulhos.

Como objetivos específicos destacaram-se: considerar a microbacia urbana como unidade básica de planejamento urbano; considerar as áreas de risco a escorregamentos como principal condicionante da urbanização; estudar critérios de urbanização em encostas de alta declividade; elaborar uma alternativa de urbanização como um ensaio prático de aplicação dos critérios estudados e de valorização do risco a escorregamentos, como condicionante dessa alternativa. 
Esta pesquisa se justificou pela necessidade de fazer-se uma reflexão sobre as formas mais adequadas de intervenções em áreas já ocupadas de encostas de altas declividades, com riscos a escorregamentos e carentes de infra-estrutura e equipamentos comunitários, valorizando os condicionantes geoambientais no estudo da urbanização.

\section{MATERIAIS E MÉTODO}

A pesquisa envolveu atividades de escritório e campo. No escritório foram realizados estudos da bibliografia pertinente, elaboração de mapas, por meio de técnicas de geoprocessamento e definição dos critérios de urbanização para o estudo de uma alternativa de urbanização. No campo, por meio de percursos programados, realizaram-se registros necessários à caracterização da área, incluindo entrevistas informais com os moradores.

Esta pesquisa foi realizada em conjunto com Gomes (2008), tendo sido o mapa de risco a escorregamento desenvolvido por essa pesquisa de fundamental importância na seleção de critérios de urbanização, que considerou o meio físico, ou melhor, o geoambiente da microbacia Taquara do Reino.

\section{LEGISLAÇÃO URBANA E AMBIENTAL}

As legislações urbanísticas e ambientais são instrumentos normativos que restringem a ocupação, constituindo, dessa maneira, instrumentos fundamentais para a urbanização.

Segundo Farah (2003), os limites gerais à ocupação de encostas no Brasil, no que diz respeito à faixa de declividade máxima aceitáveis para ocupação urbana, são bastante vagas.

O Código Florestal (BRASIL, 1965), em seu artigo 2으, define que a ocupação deve abranger terrenos de declividade de até 45 (100\%); a Lei Lehman (BRASIL, 1979), em seu artigo 3, define que não será permitido o parcelamento do solo em terrenos com declividade igual ou superior a 30\%, salvo se atendidas exigências específicas das autoridades competentes; e, no âmbito municipal, pode-se destacar a Lei de Zoneamento (GUARULHOS, 2007), na qual, em seu artigo 6으, não será permitido o parcelamento do solo em terrenos com declividade superior a $30 \%$, salvo se atendidas as exigências específicas das autoridades competentes, observando-se o limite máximo de $45 \%$.

Em relação às Áreas de Preservação Permanente (APP), essa pesquisa considerou apenas as referentes aos cursos d' água, utilizando-se do Código Florestal (BRASIL, 1965), em que a faixa marginal possui largura mínima de 30 metros para os córregos e 50 metros para as nascentes, e a Resolução n. 369/06 do Conama (BRASIL, 2006), no qual a faixa marginal possui 15 metros, devido à microbacia ser uma ZEIS. Dessa forma, a APP de topo de morro foi desconsiderada, tendo em vista que nos topos de morros estão as principais vias de circulação do transporte público e a área comercial da microbacia Taquara do Reino (Figura 5). 


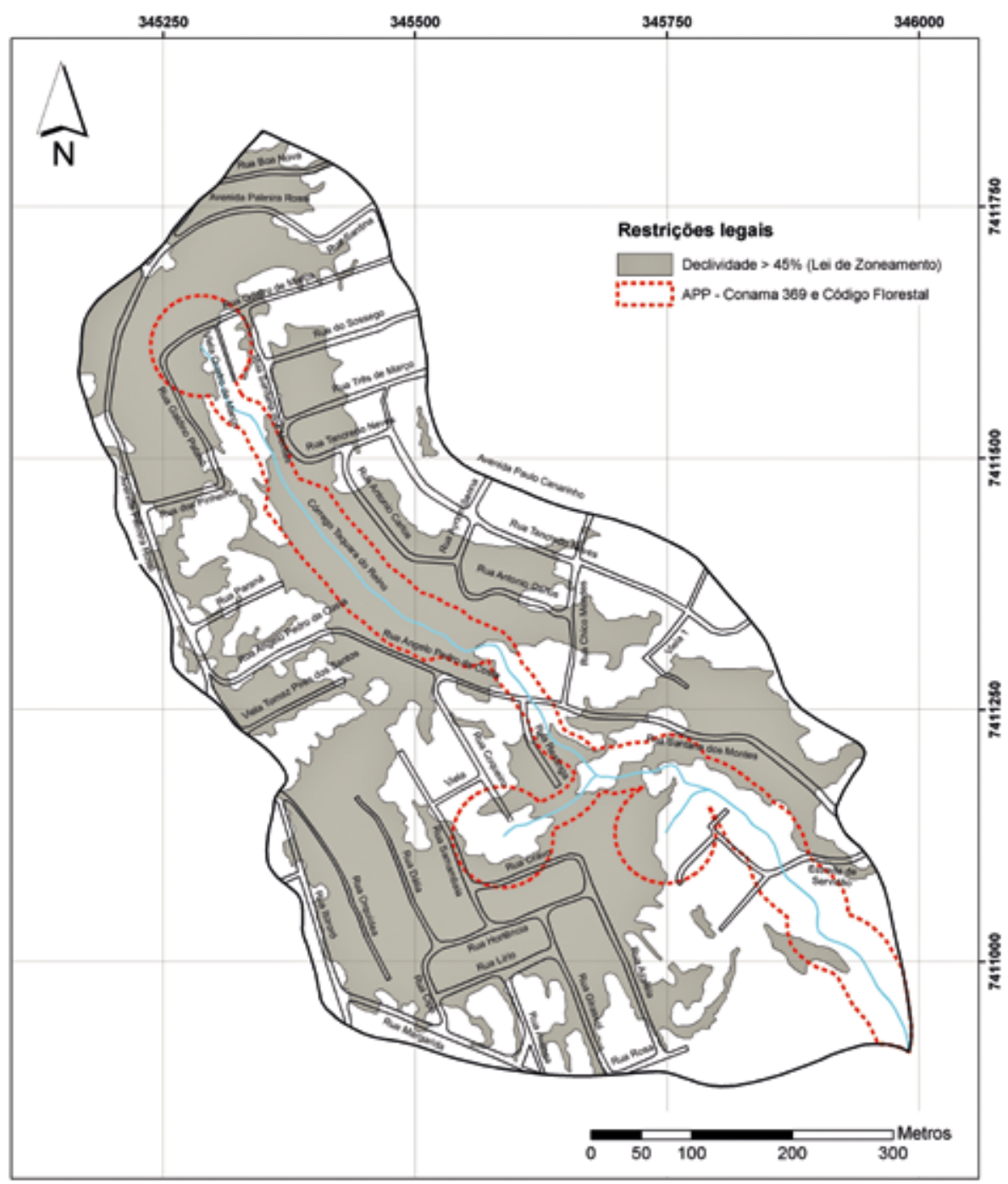

Figura 5: Mapa de restrições legais da microbacia Taquara do Reino Fonte: Sandra Emi Sato, 2008

Na Lei de Zoneamento de Guarulhos (GUARULHOS, 2007), verifica-se que a microbacia Taquara do Reino está inserida dentro da ZEIS L e sobrepõe-se à Zona de Proteção Especial - APA Cabuçu - Tanque Grande. Dessa forma, deve ser estabelecido um Plano de Urbanização, que deve atender às seguintes diretrizes:

"I - promover o desenvolvimento urbano dos assentamentos existentes, sem expansão, subordinado à recuperação e preservação do meio ambiente natural;

II - considerar os condicionantes físico-territoriais, em particular os aspectos morfológicos e hidrográficos;

III - estabelecer índices de ocupação e usos compatíveis com a recuperação e conservação do meio ambiente natural;

IV - propor alternativas habitacionais multifamiliares que permitam adensamento." 


\section{ANÁLISE GEOAMBIENTAL}

As características geoambientais da microbacia Taquara do Reino foram sinteticamente sistematizadas em uma ficha cadastral que compõe o dossiê da microbacia Taquara do Reino (OLIVEIRA et al, 2005), conforme Tabela 1.

Tabela 1: Ficha cadastral com as características geoambientais

\section{Microbacia B03 -Taquara do Reino}

\section{Localização}

\begin{tabular}{|c|c|}
\hline Bairro: Jd. Novo Recreio & Acesso: Palmira Rossi/ Paulo Canarinho/ Estr. Veigas \\
\hline \multicolumn{2}{|c|}{ Características Geométricas } \\
\hline Comprimento: $1.090 \mathrm{~m}$ & Largura máxima: $580 \mathrm{~m}$ \\
\hline Perímetro: $2.973,73 \mathrm{~m}$ & Área da bacia: 42 ha \\
\hline Altitude máxima: 880 m & Altitude mínima: $770 \mathrm{~m}$ \\
\hline Desnível: $110 \mathrm{~m}$ & \\
\hline
\end{tabular}

\section{Geologia}

Filitos, metassedimentos síltico-arenosos, metabásicas, gnaisses de filiação granítica, coluviões e sedimentos aluviais

\section{Pedologia}

Latossolos vermelho- amarelos, textura argilosa nas vertentes e gleissolos na planície aluvial (área restrita)

\section{Geomorfologia}

Microbacia com trechos das unidades regionais: morros e montanhas; morrotes paralelos

\begin{tabular}{l|l}
\hline \multicolumn{2}{|l}{ Índices Geomorfológicos } \\
\hline Área da bacia: $438.210,72 \mathrm{~m}^{2}$ & Circularidade: 0,62 \\
\hline Comprimento da rede de drenagem $(\mathrm{km}): 1,392 \mathrm{~mm}$ & Densidade de drenagem $\left(\mathrm{km} / \mathrm{km}^{2}\right): 3,17$ \\
\hline Comprimento do talvegue principal $(\mathrm{m}): 1.128,10 \mathrm{~m}$ & Desnível do talvegue: $45 \mathrm{~m}$ \\
\hline Declividade do talvegue principal: $4 \%$ & \\
\hline Compartimentos Geoambientais &
\end{tabular}

A: Aluvião/Planície fluvial/Gleissolo: área de acumulação sedimentar e escoamento fluvial.

P1: Metapelitos (intercalações de metabásicas)/Baixas declividades $(<30 \%)$ Latossolos argilosos pouco espessos: áreas onde predominam a dispersão e a infiltração de águas pluviais; erosão laminar natural pouco intensa.

P2: Metapelitos (intercalações de metabásicas)/Médias a altas declividades (> 30\%) Latossolos argilosos pouco espessos: áreas onde predominam o escoamento superficial de águas pluviais e baixa infiltração; erosão laminar natural intensa e em sulcos

\section{Comportamentos previsíveis com uso do solo inadequado}

A: Inundação, solapamento, assoreamento, recalque em fundações.

P1/P2: Em cortes: erosão intensa em sulcos; desplacamento e desconfinamento de filito/xistos; em aterros predominam os solos de alteração de rocha siltosos: erosão intensa (em sulcos, ravinas e voçorocas); movimentos de massa. 
Dessas características destacam-se as elevadas declividades, os solos rasos e o subsolo, embasamento geológico pouco permeável, que convergem para um comportamento hídrico a favorecer mais o escoamento superficial que a infiltração (LACAVA, 2007). De fato, o mapa de declividades da microbacia Taquara do Reino revela que essa microbacia é constituída, em torno de $80 \%$, de declividades acima de $30 \%$, conforme Figura 6.

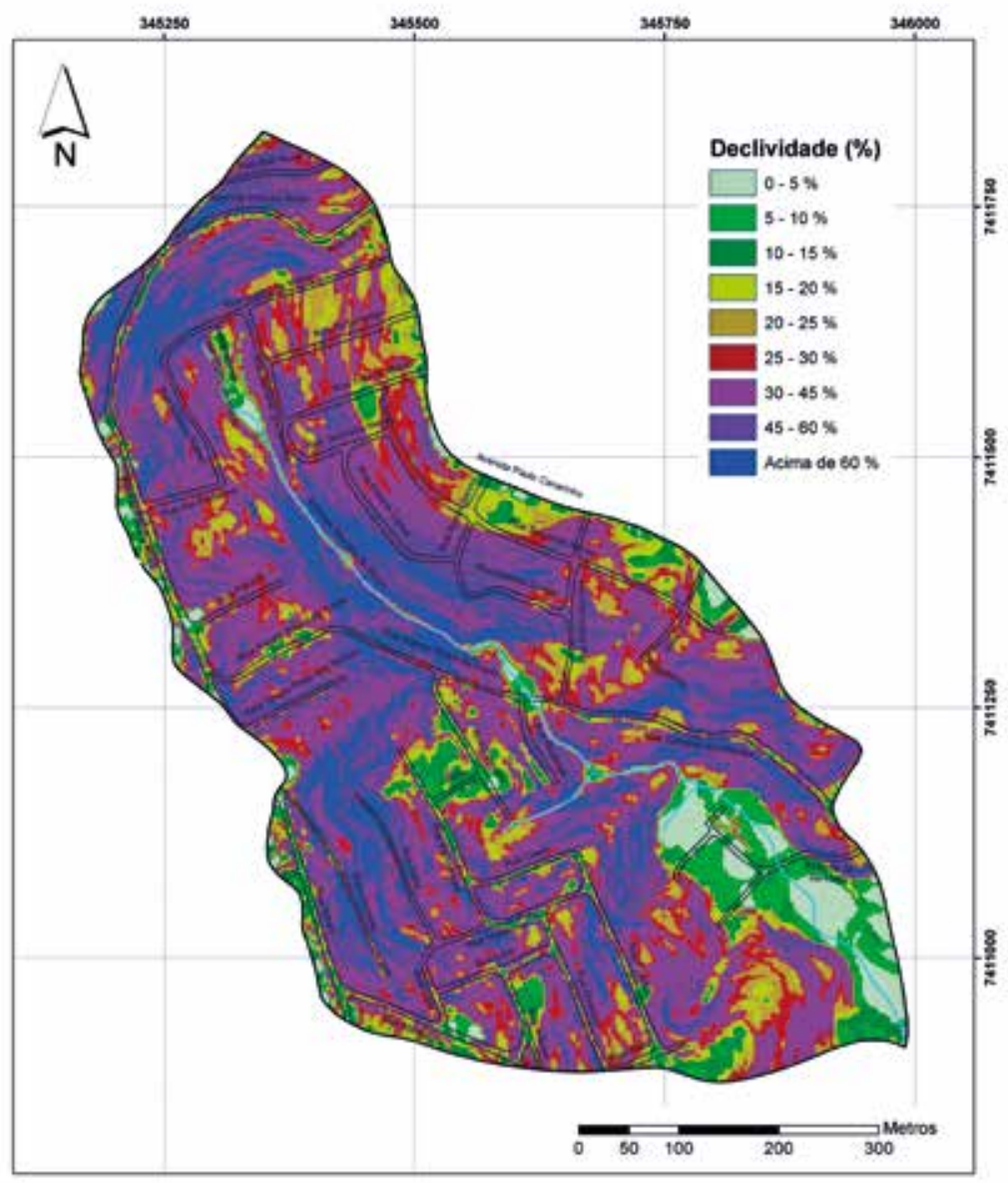

Figura 6: Mapa de declividade da microbacia Taquara do Reino Fonte: Oliveira et al, 2005

\section{PROBLEMAS AMBIENTAIS}

O mapa do sistema viário da microbacia foi o referencial para as observações de campo. Nessa atividade verificou-se que as casas que ocupam áreas com declividades superiores a 30\% utilizam técnicas de construção inadequadas, não possuem acabamento e uma parte é construída com materiais de péssima qualidade, apresentando insalubridade e umidade.

As únicas ruas que possuem pavimentação são as ruas Itororó, Margarida, a Avenca, Lírio e parte da rua Cipó. Algumas ruas são intransitáveis mesmo em períodos sem 
chuvas, como a rua dos Pinheiros, pois foram traçadas perpendicularmente às curvas de nível, apresentando declividade acentuada e, por causa da ausência de obras de drenagem urbana, apresentam erosões na forma de sulcos e ravinas, devido às águas pluviais e ao lançamento de água servida, conforme a Figura 7.

O lançamento de lixo e entulho em terrenos vazios e nas encostas é frequente, mesmo havendo coleta de lixo semanalmente realizada por um caminhão especial, com tração nas quatro rodas e de menor porte, para acessar as ruas com declividade acentuada (Figura 8). Além disso, existem algumas lixeiras comunitárias feitas de concreto e caçambas de lixo distribuídas pela microbacia.
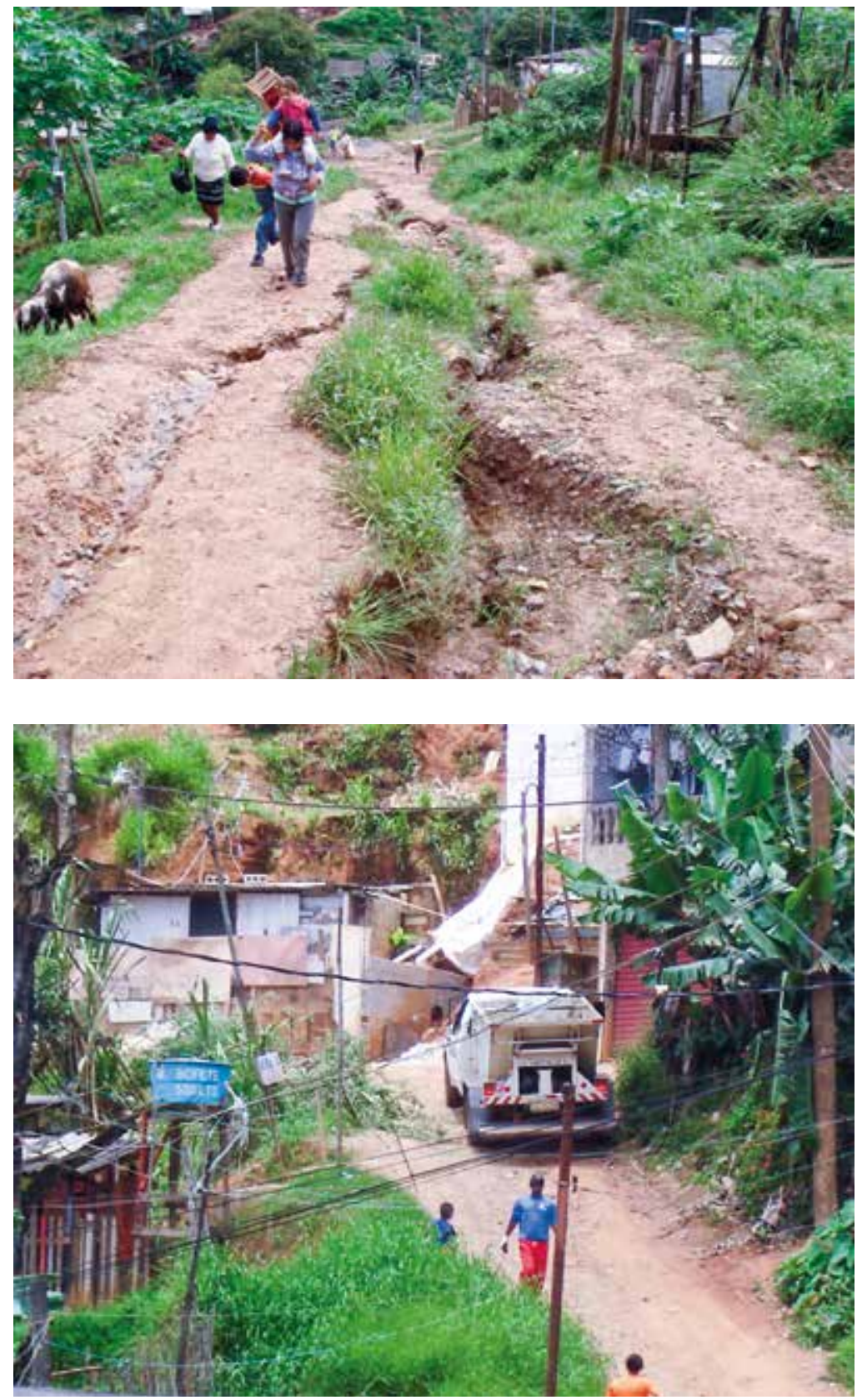

Figura 7: Vista dos sulcos e ravinas na rua dos Pinheiros

Foto: Sandra Emi Sato, 15 dez. 2007
Figura 8: Fotografia do caminhão especial de coleta de lixo

Foto: Sandra Emi Sato, 13 dez. 2006 
A rede de água é insuficiente, pois não chega a alguns pontos da microbacia e os moradores também sofrem com o racionamento. Onde não há rede de água, a população utiliza a nascente do córrego Taquara do Reino. Essa água, segundo uma análise do $\mathrm{SAAE}$, é imprópria para o consumo devido à contaminação por coliformes fecais.

A rede de drenagem pluvial é precária, a maioria das ruas não possui sarjetas, boca de lobo e galerias de águas pluviais. Em algumas ruas foram observadas canaletas, mas todas essas obras estavam inacabadas, com sérios riscos de acidente (Figura 9). Há algumas escadas d' água, mas estão maldimensionadas e sem manutenção.

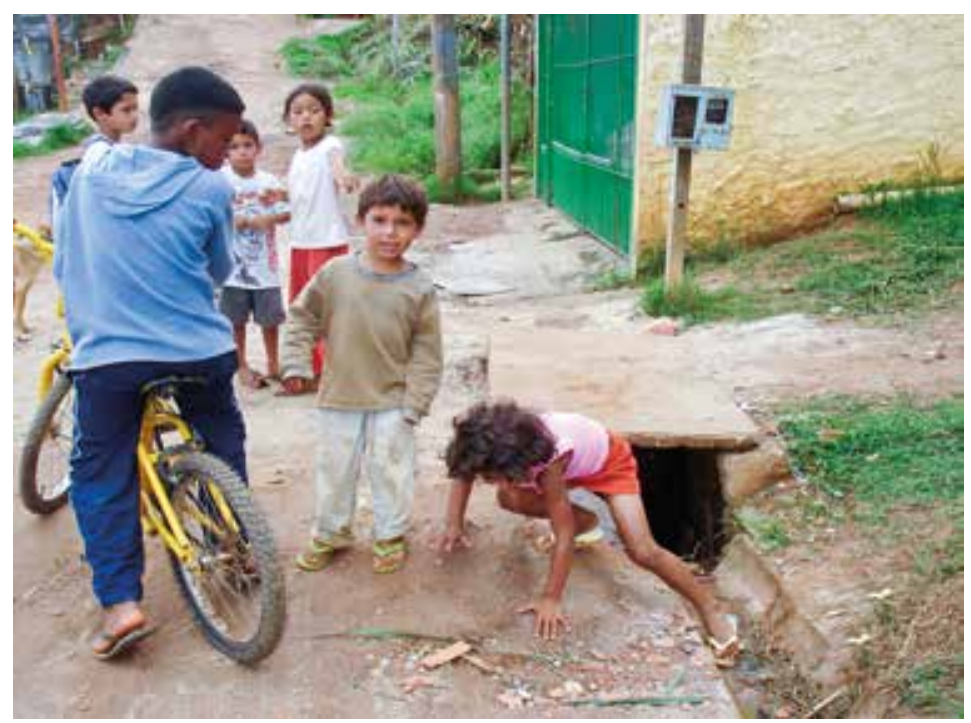

Figura 9: Vista do bueiro em condição precária

Foto: Sandra Emi Sato, 13 dez. 2006

Os problemas ambientais levantados nesta pesquisa foram analisados com base na monografia Impactos geoambientais da ocupação urbana na microbacia Taquara do Reino - Bairro Novo Recreio, município de Guarulhos, SP (QUEIROZ, 2005), que teve como objetivo realizar um diagnóstico dos principais problemas geoambientais, especificamente solos e águas, ocorridos em virtude da ocupação urbana irregular.

Verificou-se em campo, período de 2006 a 2008, que a maioria dos problemas levantados por Queiroz (op. cit.) permanecem e a principal atualização necessária refere-se às áreas de risco e suscetibilidade a escorregamentos, elaborada por Gomes (2008).

\section{Áreas de riscos a escorregamentos}

Existem vários processos do meio físico, do ponto de vista geológico e geotécnico que, se não forem considerados, podem conduzir a prejuízos ambientais e econômicos, como também ao risco de morte nas ocupações inadequadas de encostas. Um desses principais processos geoambientais são os escorregamentos.

Atualmente, dispõe-se de métodos adequados à abordagem do problema de risco a escorregamentos. Nessas abordagens, a análise das condições geoambientais e de ocupação leva à elaboração do mapa denominado mapa de risco a escorregamentos, no qual, em geral, são classificadas as áreas de alto, médio e baixo riscos (GOMES, 2008). 
A Figura 10 mostra o mapa de zoneamento de risco e suscetibilidade a escorregamentos elaborado por Gomes (op. cit.), realizado com base no mapa de declividades, mapa de uso do solo, mapa geológico e cicatrizes de escorregamentos verificados em campo.

No campo verificou-se que todos os escorregamentos cadastrados ocorreram em declividades superiores a $60 \%\left(30^{\circ}\right)$, mobilizando aterros com entulho e lixo nas encostas (Figura 11). Essa tipologia de escorregamentos torna evidente o impacto da ocupação inadequada das encostas de alta declividade, representada pelos cortes e

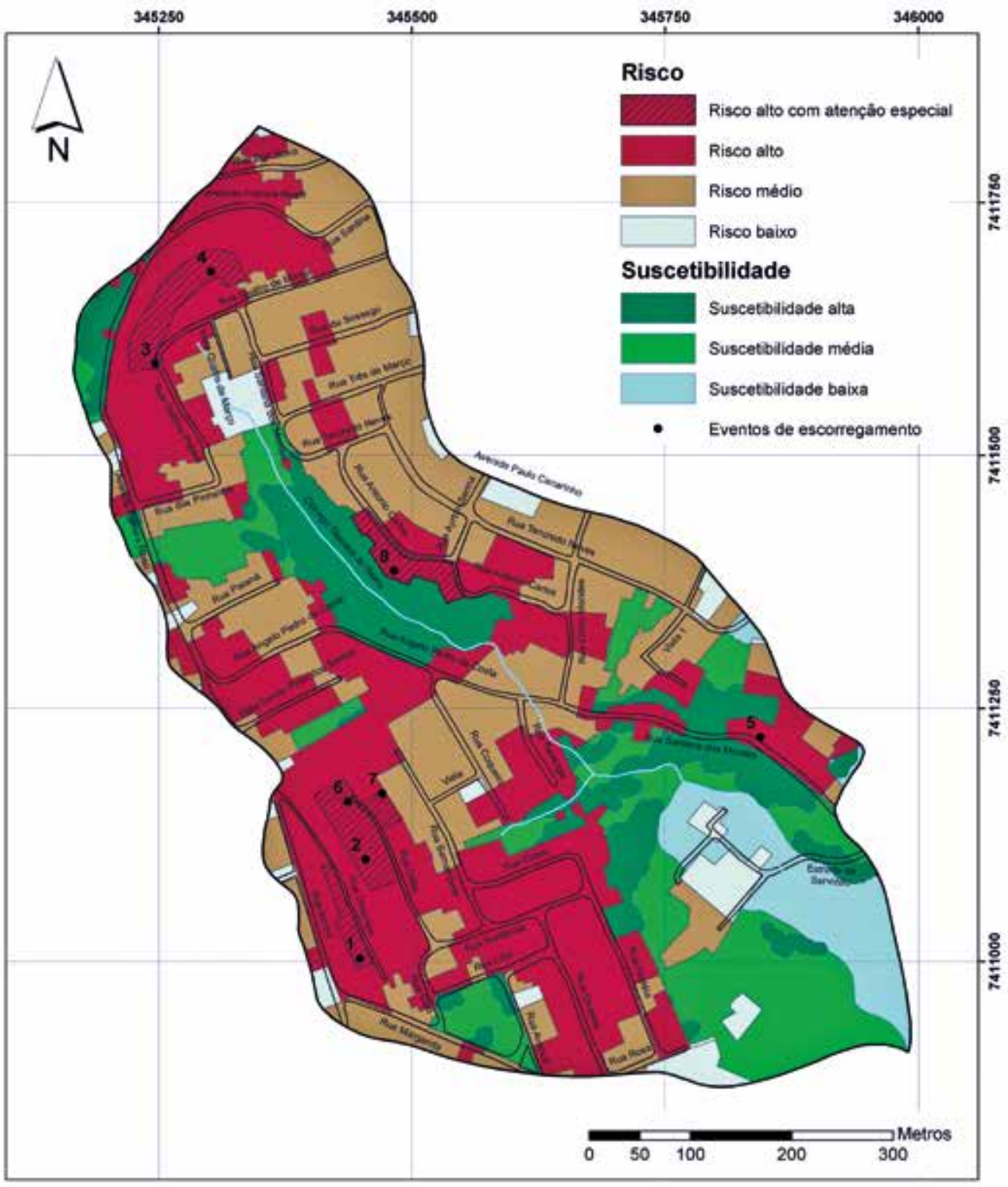

Figura 10: Mapa de zoneamento de risco e de suscetibilidade a escorregamento da microbacia 


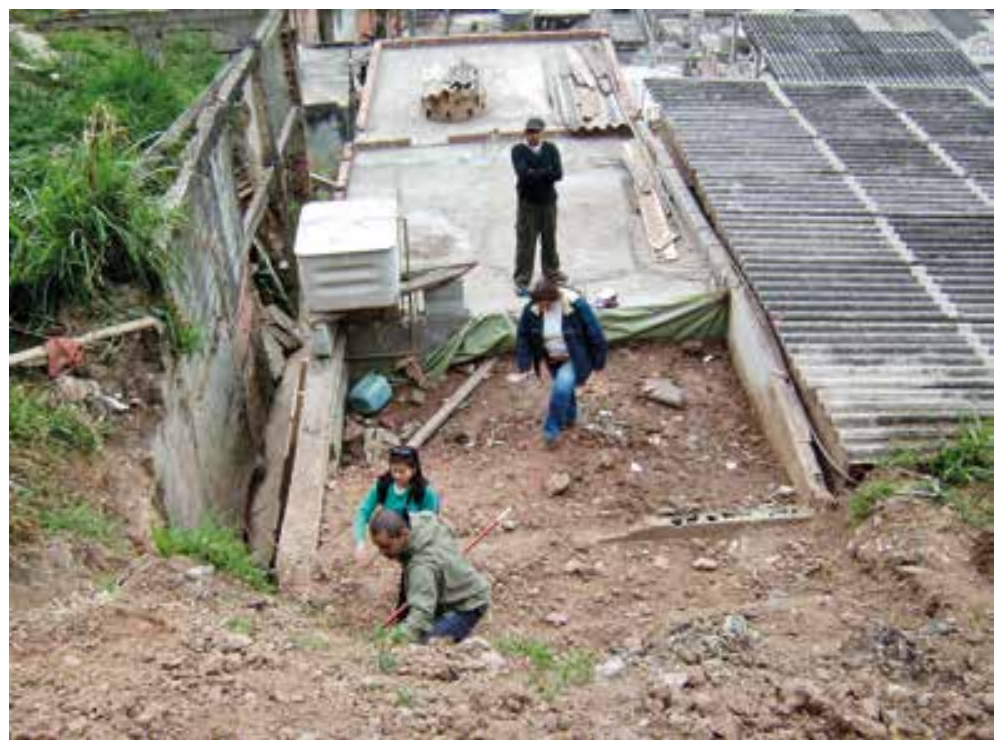

Figura 11: Vista parcial de um escorregamento Foto: Sandra Emi Sato, 15 set. 2007

aterros para a edificação das moradias. O lançamento de solo formando os aterros, misturados a entulho e lixo, constituem o principal condicionante dos escorregamentos nas encostas de altas declividades. Ou seja, tratam-se de escorregamentos induzidos por ação antrópica, por meio de cortes e aterros, e sujeitos à declividade como principal condicionante natural (GOMES, op. cit.).

No mapa de risco e suscetibilidade a escorregamentos, elaborado por Gomes (op. cit.), verifica-se que o valor da declividade limite é 60\%, superior aos valores das legislações pertinentes (30 e 45\%), tendo sido adotado nesta pesquisa como critério de identificação de áreas, cujas moradias têm de ser avaliadas quanto à necessidade de remoção.

\section{UM ESTUDO DE URBANIZAÇÃO COM BASE EM CONDICIONANTES GEOAMBIENTAIS}

Pela análise de critérios de ocupação em encostas de alta declividade e de medidas de controle do risco a escorregamentos, processos que constituem um dos principais condicionantes geoambientais de urbanização de encostas, foi proposta uma alternativa de urbanização para a microbacia Taquara do Reino. Os itens a seguir expõem as análises realizadas e a referida proposta.

\section{Critérios de ocupação em encostas de alta declividade}

As encostas de elevada declividade constituem unidades geoambientais vulneráveis a desequilíbrios do meio ambiente, correspondentes a escorregamentos, condicionados por processos naturais e/ou antrópicos, colocando em risco edificações e moradores. Portanto, a ocupação e quaisquer intervenções nas encostas necessitam de tratamentos específicos desses problemas, integrados com os demais tratamentos referentes aos critérios de ocupação em encostas de alta declividade. 
Dessa maneira, é fundamental, inicialmente, considerar critérios de urbanização propostos por diversos autores como Moretti (1987), Cunha (1991), Mascaró (1994) e Farah (2003). Com base nesses autores, os critérios podem ser considerados em grupos temáticos principais, embora a ocupação se caracterize por uma plena conexão e inter-relação dos temas: sistema viário, drenagem superficial, saneamento básico e habitação.

Os critérios considerados em cada um desses temas têm como principal preocupação, especificamente, a prevenção de processos geológicos como erosão e assoreamento, e, especialmente, escorregamentos, devido aos danos que eles provocam.

O sistema viário tem papel fundamental na definição do modo de ocupação em encostas. Portanto, sua implantação deve ser ajustada à conformação do terreno, reduzindo ao máximo o movimento de terra e assegurando proteção adequada às áreas vulneráveis. A hierarquização do sistema viário é necessária para definir funções para cada tipo de via, evitando os conflitos de usos e ajustando às declividades. Nesse sentido, as vias principais seriam mais largas, devido ao grande tráfego de veículos e pedestres e estariam em áreas de menores declividades, diminuindo o volume de terraplenagem; e as vias locais, que priorizam a circulação de pedestres, poderiam estar em declividades mais acentuadas e seriam mais estreitas, para minimizar os problemas geotécnicos. Dessa maneira, as vias principais, com maior tráfego, e as vias locais de maiores declividades deveriam ser pavimentadas para evitar a erosão.

A drenagem superficial se faz pelas linhas d'água naturais e pelo sistema formal construído, que deve estar harmonizada com as feições do relevo para permitir o efetivo escoamento das águas (FIDEM, 2004). Dessa maneira, as linhas de drenagem natural de fluxo permanente devem ser preservadas e o sistema viário deve estar integrado às linhas de drenagem nas quais o escoamento da água não é permanente. Dessa forma, o escoamento da água pluvial e servida escoaria do topo à base da encosta, evitando a concentração da água, garantindo a trafegabilidade de veículos e pedestres e impedindo o desenvolvimento de processos erosivos, de assoreamento e de enchentes.

Quanto ao saneamento básico, tendo em vista o fato de os processos geológicos estarem associados ao comportamento do escoamento superficial e infiltração da água, trata-se de uma infra-estrutura importante a ser considerada, sendo ideal que a implantação de rede de água e esgoto sanitário seja realizada em toda a microbacia, pois a presença de fossas, especialmente em aterros, constitui fator que potencializa os escorregamentos.

As ocupações em encostas devem conceber tipologias habitacionais adaptadas aos terrenos, onde o corte e/ou aterro tenha uma inclinação adequada que dispense a necessidade de estrutura de contenção e seja gerada de maneira balanceada, evitando a importação e exportação de volume de terra significativo. Os lotes em terrenos com declividade acentuada devem ser implantados com a maior dimensão ao longo das curvas de nível, evitando significativas modificações do perfil topográfico e, assim, de movimentos de terra que possam aumentar a suscetibilidade local a processos geológicos. 
Enfim, os parâmetros urbanísticos utilizados necessitam de valores específicos para as encostas, para que o trabalho de terraplenagem possa ser minimizado. Dessa maneira, os valores da largura das vias, da rede de drenagem, taxa de ocupação, coeficiente de aproveitamento e recuos das edificações podem variar de acordo com a declividade natural do terreno.

\section{Critérios relativos ao controle a escorregamentos}

Pode-se considerar que medidas preventivas do risco geológico correspondem àquelas que acompanham um planejamento adequado do uso do solo, evitando a ocupação de áreas impróprias determinadas pelas classes de suscetibilidade aos processos.

Após uma ocupação inadequada ter-se efetivada, havendo geração de áreas de risco, as medidas que vierem a ser tomadas terão caráter corretivo, de maior ou menor intensidade, determinadas em função da distribuição e características das áreas de diferentes graus de risco a escorregamentos.

As áreas de alta suscetibilidade a escorregamentos devem ter sua ocupação evitada, mantendo-se sua vegetação natural e mesmo reflorestando a área quando necessário.

Para as áreas de risco alto foi indicada a remoção de famílias. Essas áreas de risco alto, que não podem ser corrigidas enquanto ocupadas, deveriam ser interditadas, passando a servir como áreas de uso comum, protegidas por vegetação, evitando novos processos de ocupação. Entretanto, quando as áreas são extensas, e é grande o número de famílias sujeitas ao risco, é necessário estabelecer prioridades de remoção, definindo-se critérios adequados para tal.

As intervenções que prejudicam as condições de estabilidade da encosta, como a retirada de vegetação, cortes e aterros, lançamento de águas servidas e pluviais, obstrução da drenagem natural e construída, plantação de bananeiras, etc., deveriam ser proibidas. Da mesma forma, a construção de fossas, sumidouros ou valas de infiltração nas encostas já referidas.

Os serviços de limpeza de lixo e entulho das encostas, do sistema de drenagem, esgotos e no sistema viário deveriam ser adequados para que não ocorra a saturação dos materiais em condições instáveis, potencializando o escorregamento.

Finalmente, deveria ser criado o Plano Preventivo de Defesa Civil (CERRI; AMARAL, 1998), que visa estabelecer um conjunto de ações preventivas, assistenciais, emergenciais e reconstrutivas destinadas como medidas de controle dos desastres.

Em todas as medidas de controle a escorregamentos, a participação da comunidade é fundamental e deveria ser contemplada pela educação ambiental, por meio de informações públicas, capacitação para ações preventivas e autodefesa para a comunidade.

\section{Estudo de uma alternativa de urbanização}

Esse estudo de urbanização foi realizado com o objetivo de testar-se a aplicação dos critérios de ocupação em encostas de alta declividade e de medidas de controle 
de risco a escorregamentos, acima discutidos, em um caso prático - o da microbacia Taquara do Reino.

É importante destacar que esse estudo constitui uma alternativa, pois outras alternativas poderiam ser consideradas um processo real, que leve em conta, além desta pesquisa, outros fatores condicionantes, especialmente, a participação da população nas decisões a serem tomadas, a regularização fundiária e os custos das medidas e obras consideradas.

O desenvolvimento do estudo foi ao encontro das quatro diretrizes propostas, no artigo 36 da Lei de Zoneamento (GUARULHOS, 2007), para o Plano de Urbanização das ZEIS que se sobrepõe à APA Cabuçu - Tanque Grande.

Na diretriz um deste artigo, para o desenvolvimento urbano dos loteamentos Recreio São Jorge e Novo Recreio é proposto, por esta pesquisa, que o estudo de urbanização ocorra dentro dos limites da microbacia Taquara do Reino, para que a recuperação e a preservação do meio ambiente natural ocorram de maneira sistêmica e integrada.

Considerar os condicionantes físico-territoriais, em particular os aspectos morfológicos e hidrográficos, conforme exposto na segunda diretriz, foi fundamental para esta pesquisa, tendo em vista que o risco a escorregamento foi o condicionante principal para a urbanização.

A diretriz três foi trabalhada, parcialmente, pela APP referente aos cursos d'água, nos quais foi proposta a criação, nessa faixa de preservação, de áreas de lazer, recreação, além do reflorestamento em áreas de altas declividades.

E, finalmente, esta pesquisa propõe habitações multifamiliares dentro da própria microbacia Taquara do Reino, baseada no meio físico, conforme a quarta diretriz.

Para as concepções realizadas no estudo foi fundamental a realização dos percursos no campo, pois, por meio deles, foi possível conhecer melhor a microbacia de estudo e entender os processos naturais e antrópicos presentes. Além disso, cada percurso permitiu uma maior interação com os moradores, criando oportunidades de eles expressarem seus desejos, valores, preocupações e necessidades para a área.

\section{Critérios para remoção}

A relocação, com a construção de unidades habitacionais na própria microbacia, pode ser considerada a melhor maneira de remanejar as famílias que seriam removidas, pois respeita sua dinâmica social.

Com o software ArcGis 9.2 (Environmental Systems Research Institute - ESRI), foram sobrepostas, na imagem de satélite QuickBird de 2005, as cartas de restrições legais e de risco a escorregamento para verificar as casas que seriam removidas.

Os critérios estabelecidos para a desapropriação foram as habitações precárias ou barracos localizados em áreas de risco alto com escorregamento recente (áreas de atenção especial) e moradias dentro da APP marginal ao curso d' água. Quanto às construções feitas com materiais de melhor qualidade, a PMG deveria proporcionar algum tratamento de engenharia visando eliminar a possibilidade de instabilizações da 
encosta, opção essa baseada na relação custo da obra versus valor da desapropriação. A Figura 12 apresenta as moradias a serem removidas.

\section{Plano de quadra e tipologia das edificações}

Nesse estudo de urbanização, as quadras e a tipologia das edificações não sofreriam mudanças. As moradias continuariam ao longo das encostas, enquanto as áreas planas seriam destinadas às construções de tipologias habitacionais multifamiliares, adaptadas ao terreno, para relocação das famílias removidas.

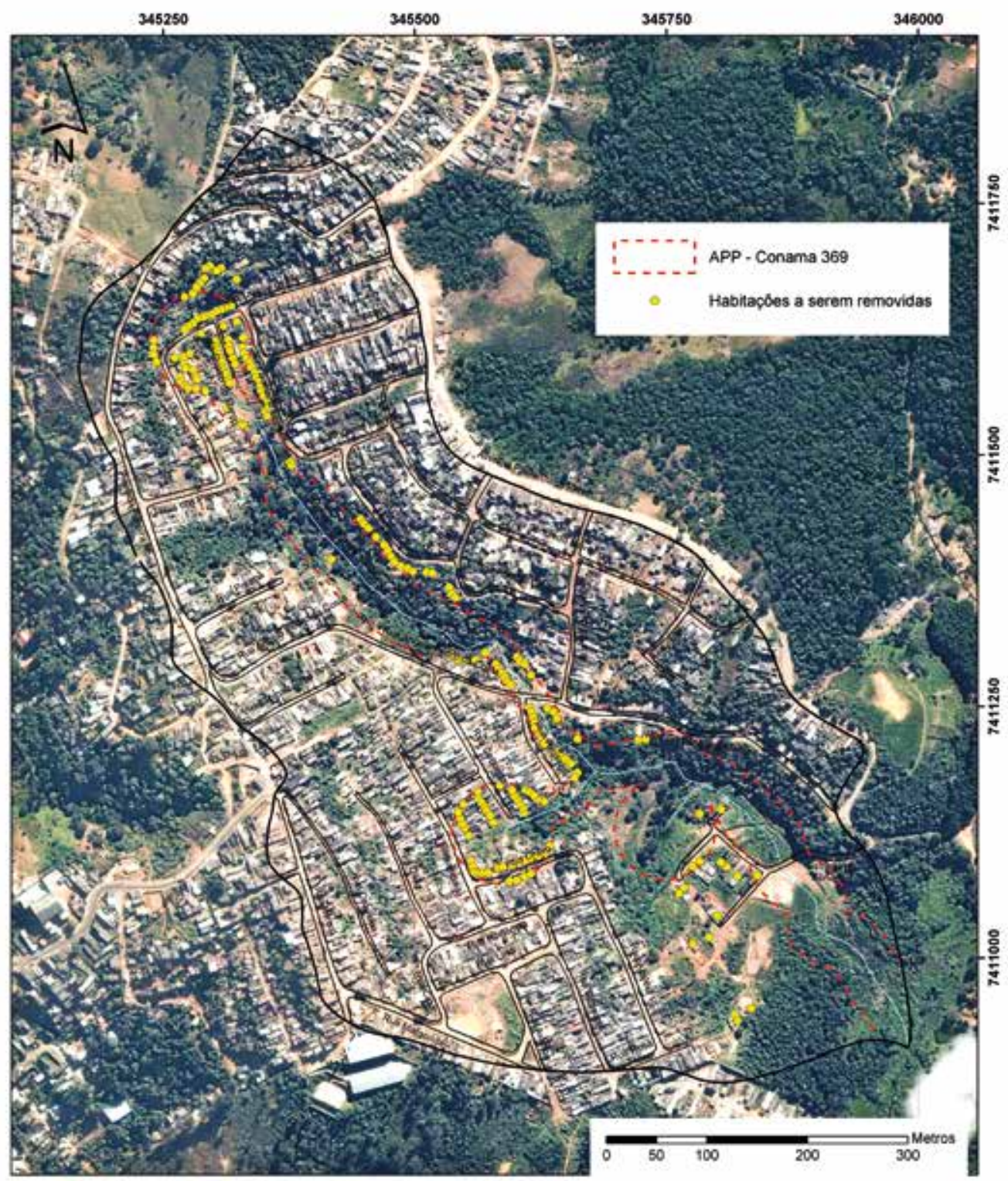

Figura 12: Mapa de remoções da microbacia Taquara do Reino Fonte: Sandra Emi Sato, 2008 
A proposta explora a verticalização na área mais plana, pois essa permite, pelo adensamento da área, a liberação de porções de terreno para paisagismo e lazer. $\bigcirc$ gabarito fica definido como 4, conforme o artigo 38 da Lei de Zoneamento (GUARULHOS, 2007).

\section{Sistema viário}

Procurou-se, no estudo, preservar o traçado do sistema viário. Mesmo as vias que possuem altas declividades foram preservadas, pois o custo para remodelar todo o sistema viário, conforme a inclinação ideal estabelecida pelas leis urbanísticas, estima-se ser muito alto, tendo em vista a necessidadede de remover-se muitas famílias.

Mas foi proposta a hierarquização do sistema viário para definir funções para cada tipo de via, evitando-se os conflitos de usos. $\bigcirc$ sistema viário principal, por onde passam os transportes públicos e encontram-se as áreas comerciais e institucionais, deveria possuir uma via mais larga e ser implantada em área de menor declividade, o que, no caso da microbacia Taquara do Reino, já ocorre nos topos de morros (ruas Margarida, Itororó e avenidas Palmira Rossi e Paulo Canarinho). Já as vias locais, que priorizam a circulação de pedestres, os acessos às edificações e aos recantos deveriam possuir ruas mais estreitas nas encostas, para reduzir os volumes de terraplenagem.

As vias locais, os becos, as passagens de uso comum e as escadarias poderiam possuir variação na largura em pontos estratégicos para que esses locais fossem utilizados como espaço de lazer e convívio. Esses pontos funcionariam como os pequenos recantos que existem na microbacia, mas devem ganhar um tratamento paisagístico para melhorar o conforto e o aproveitamento do espaço.

As vias por onde circulam os transportes públicos e as vias onde ocorrem problemas de trafegabilidade, devido à falta de drenagem superficial e a declividade acentuada, deveriam ser pavimentadas com lajotas de concreto para evitar problemas com erosões. De acordo com o Diário Oficial, de 13 de abril de 2007, esse tipo de material é utilizado pela Secretaria de Obras e Serviços Públicos da PMG, no programa de Mutirão Comunitário.

Na vertente direita foi criada uma via que liga a rua Santana dos Montes à Galdino Pataxó, criando um grande corredor que circunda a APP. E, próximo ao exutório da microbacia, foi proposto o prolongamento da rua Rosa até a estrada de Servidão para atender às habitações multifamiliares criadas para as famílias removidas.

\section{Drenagem urbana}

O sistema de microdrenagem considerado incluiria calhas, canaletas de bordas e de pé dos taludes, canaletas de descida entre patamares e canaletas principais que recolhem as águas pluviais e servidas, escoando-as do topo à base das encostas, até o córrego Taquara do Reino. Deve-se prever a aplicação de ranhuras nas vias pavimentadas com declividade acentuada para conduzir as águas até as canaletas. 
Devido à declividade acentuada, dever-se-ia optar pelas escadas d'água, como canaletas abertas, com fundo construído em forma de degraus, visando reduzir a velocidade das águas superficiais (CUNHA, 1991). Na microbacia já existem algumas escadas d'água, mas outras deveriam ser criadas, considerando as principais linhas de drenagem e áreas de convergência da água, conforme Figura 13.

Na microbacia Taquara do Reino é possível a implantação de uma bacia de estocagem de águas pluviais (MASCARÓ, 1994) para evitar o transbordamento do córrego, evitando inundações.

\section{Saneamento de água}

A ausência de sistema de esgoto nesses loteamentos tem levado os moradores a seguir práticas inadequadas para o destino de seus efluentes domésticos, como utilização de fossas sépticas ou lançamento direto no solo, verificando-se que vários escorregamentos foram deflagrados por fossas que promoveram infiltração (GOMES, 2008).

Dessa maneira, este estudo considera que cada unidade habitacional teria instalação sanitária mínima, permitindo ligação ao sistema implantado. A água do esgoto deveria ser obrigatoriamente separada das demais águas, pois seguiria para tratamentos e destinos diferenciados.

Essa concepção considera que as tecnologias para a coleta de esgoto mais adequadas às condições encontradas nos morros é a do sistema condominial, que se baseia na definição da unidade de atendimento, deixa de ser o lote e passa a ser o conjunto de domićlios vizinhos em uma mesma quadra. Por sua vez, essa unidade ou condomínio é interligada à rede pública por meio de um ramal condominial. Após a coleta pela rede pública, o esgoto bruto pode passar por um sistema alternativo de tratamento chamado de alagado construído, que pode ser constituído por leito escavado com um metro de profundidade, 80 metros de comprimento e 20 metros de largura (LAUTENSCHLAGER, 2001).

As grandes vantagens dessa proposta são os baixos custos de implantação e manutenção, ausência de odor e fácil monitoramento.

\section{Resíduos sólidos}

A microbacia Taquara do Reino já possui um sistema de coleta de lixo diferenciado, devido à inclinação de suas vias, um caminhão de menor porte e com tração nas quatro rodas realiza a coleta duas vezes por semana, recolhendo o lixo das caçambas e lixeiras comunitárias, além dos coletores que retiram os sacos de lixo colocados na frente das casas.

Mas o maior problema é a falta de acesso de vários moradores a essas lixeiras, o que resulta no lançamento de lixo nas encostas e nas linhas de drenagem.

Essa situação indica a necessidade de aumentar-se o número de lixeiras comunitárias, distribuí-las da melhor forma, realizar a coleta de lixo diariamente e contratar moradores como apoio aos serviços de limpeza pública. 


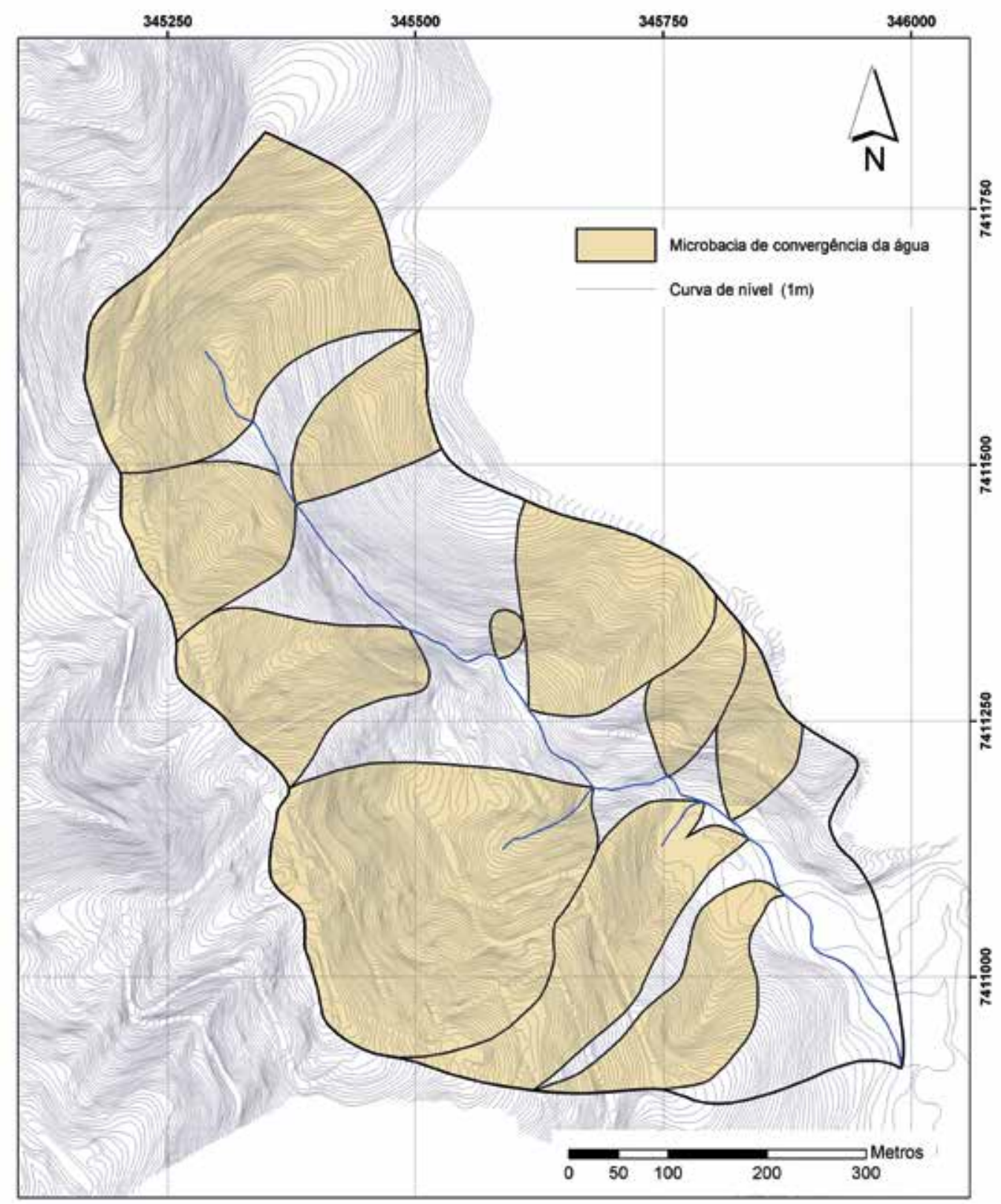

Figura 13: Mapa de drenagem superficial da microbacia Taquara do Reino Desenho: Sandra Emi Sato, 2008

critério da distribuição das lixeiras comunitárias devem levar em consideração o fluxo de pedestres nas vias, o tipo de ocupação e as distâncias às moradias. Dessa maneira, as lixeiras comunitárias poderiam ser implantadas nas principais vias de transporte público, nas ruas com acesso às vias pincipais e áreas de lazer e convívio.

Além disso, não se pode deixar de considerar a necessidade da educação ambiental, visando sensibilizar a população a mudar seus hábitos em relação à destinação do lixo, melhorando, dessa maneira, os problemas com a saúde pública e a redução das áreas de risco a escorregamentos e enchentes. 


\section{Equipamentos comunitários e sociais}

Conforme artigo 35 da Lei de Zoneamento (GUARULHOS, 2007), deverá ser criado um conselho gestor para cada ZEIS, que será composto de membros do executivo e da sociedade civil. Além disso, a própria APA que está sendo criada também exige a formação de um conselho gestor semelhante.

Dessa maneira, é necessário criar espaço para associações de bairro, com o intuito de fortalecer a comunidade para conseguir melhorias para a região, dentro dos programas Orçamento Participativo e Mutirão Comunitário, como também na participação e na implementação do Plano de Urbanização dessa ZEIS.

Além disso, nos espaços assim criados poderiam ser realizados cursos de educação ambiental e cursos profissionalizantes para a população.

Como a microbacia Taquara do Reino possui declividade acentuada e quase não há espaços livres, a implantação de equipamentos comunitários e sociais deve ser realizada em edificações já existentes.

\section{Espaços livres de uso público}

Além da criação de recantos em pontos estratégicos, esta pesquisa optou por utilizar a APP ao longo do córrego Taquara do Reino para a implantação de espaços destinados às áreas verdes para lazer e recreação.

Assim, elaborou-se um zoneamento da APP, no qual os critérios para o uso e ocupação dessa área foram:

- as matas existentes devem ser preservadas;

- as áreas que devem ser reflorestadas com árvores nativas são as encostas com declividade superior a $30 \%$;

- as áreas destinadas aos parques públicos estão na faixa da APP com declividades mais suaves. Esses parques deverão ser equipados com playgrounds, campo de futebol, bancos e mesas de jogos, pista para caminhadas e equipamentos para exercícios físicos, além da bacia de estocagem;

- a jusante, próximo ao exutório, propôs-se a instalação do sistema de alagado construído.

Respeitando as APPs, a criação das áreas verdes deverá trazer múltiplos benefícios à comunidade, como a redução da incidência e efeitos de enchentes, redução da erosão do solo e da sedimentação no canal, mitigação do calor e criação de áreas para recreação.

\section{Área para relocação}

Com a análise da imagem de satélite e dos trabalhos de campo foram identificadas as áreas livres para a relocação das famílias removidas.

Em seguida, por sobreposição da carta de declividade foi delimitada criteriosamente a área, cuja classe varia de 5 a $45 \%$, localizando-se próximo ao exutório do córrego Taquara do Reino e com área de, aproximadamente, $17.500 \mathrm{~m}^{2}$. 


\section{Trabalho em sistema de mutirão}

A proposta de urbanização da microbacia Taquara do Reino considera que as obras poderão ser implantadas pelo programa de Mutirão Comunitário, que abrange a pavimentação de ruas e vielas, o alinhamento de guias e sarjetas, drenagem, instalação de água e esgoto, muro de contenção, concretagem em vielas, construção de áreas de lazer, paisagismo e iluminação pública.

Com efeito, de um lado, a prefeitura, por intermédio da Secretaria de Obras e Serviços Públicos, oferece apoio técnico e todo o material e, de outro, os moradores entram com a mão de obra, reduzindo, dessa maneira, os custos das obras.

Todo esse trabalho pode ser realizado nos finais de semana, podendo ser útil para melhorar o convívio social entre os moradores.

A escolha dos locais que receberiam essas benfeitorias seria definida pelo Orçamento Participativo com participação dos moradores.

\section{Alternativa de urbanização}

A Figura 14 apresenta o mapa de alternativa de urbanização proposta com todas as intervenções consideradas.

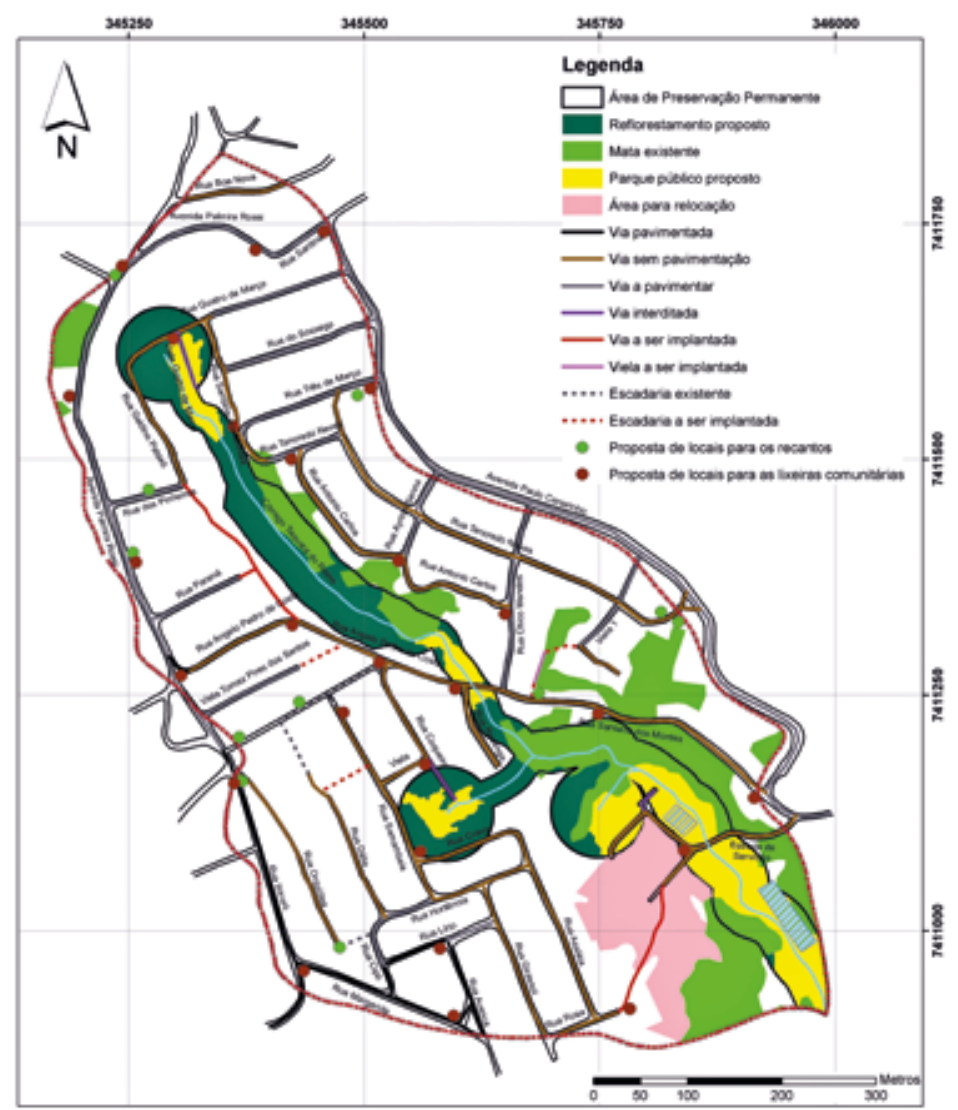

Figura 14: Desenho da proposta de urbanização para a microbacia Taquara do Reino Fonte: Sandra Emi Sato, 2008 


\section{CONCLUSÃO}

O diagnóstico geoambiental por microbacia urbana, revelando as relações existentes entre os componentes do meio físico e mostrando as vocações de cada espaço dentro da microbacia, foi útil para definir a área como unidade de planejamento, em escalas maiores que 1:5.000.

Entretanto, verificou-se que o estudo não pode ficar restrito a ela, sendo necessário também contemplar a mancha urbana como um todo (Figura 15), para que se tenha uma visão integrada da área de estudo e seu entorno, fazendo-se as inter-relações necessárias com as outras microbacias, em um planejamento mais regional.

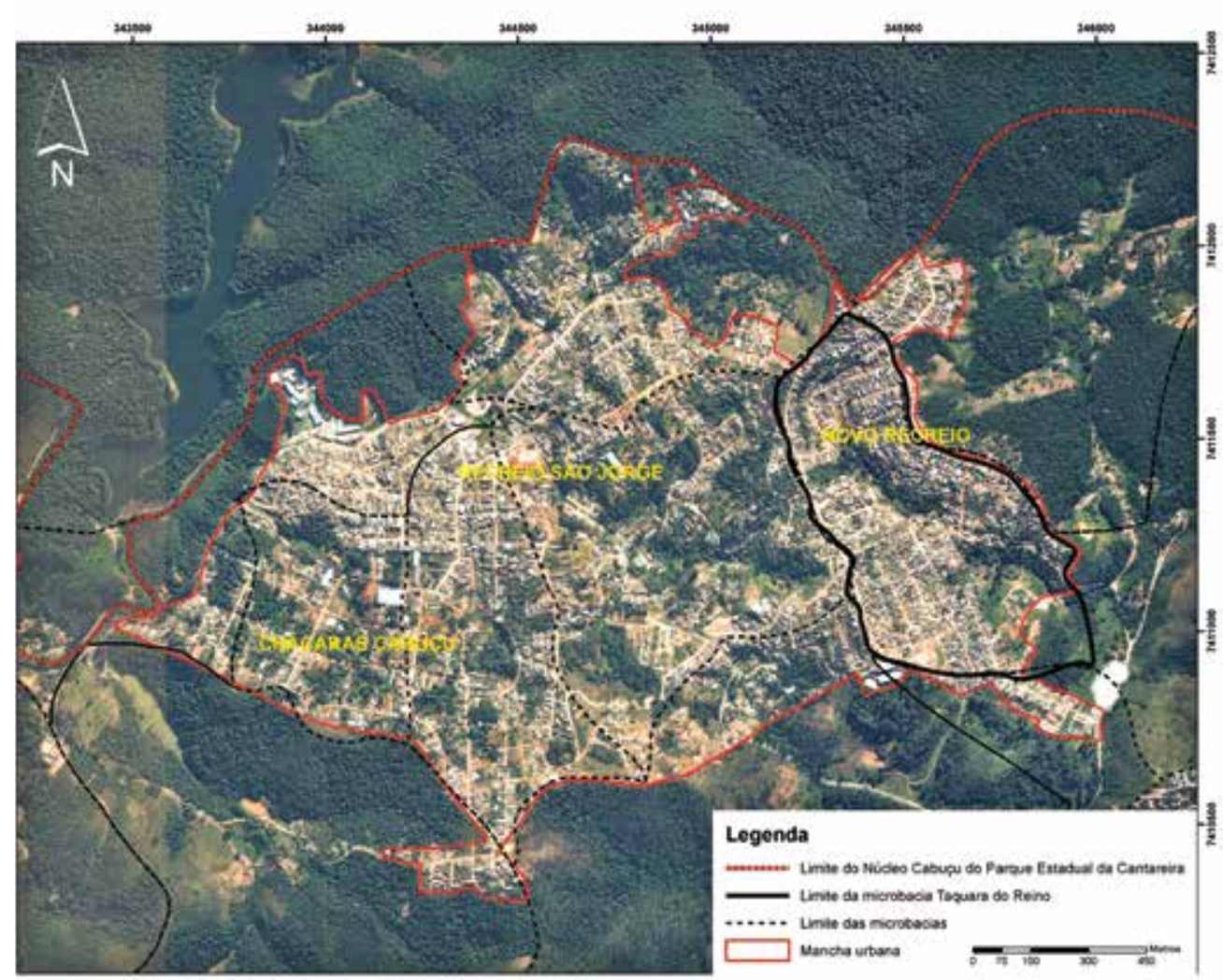

Figura 15: Mapa de localização da maior mancha urbana da zona de defesa do Núcleo Cabuçu do Parque Estadual da Cantareira

Fonte: Sandra Emi Sato, 2008

Dessa maneira, a atividade de planejamento requer várias escalas de abordagem, do regional ao local, embora se tenha confirmado a importância da microbacia como unidade básica de planejamento, especialmente quando os principais problemas são de caráter geoambiental, destacando-se loteamentos ou bairros com áreas de risco a escorregamentos, como é o caso da microbacia Taquara do Reino.

Como o risco a escorregamento é o principal condicionante geoambiental dessa microbacia, foi necessário levar em conta os resultados da análise geoambiental, ex- 
pressos cartograficamente pela carta de suscetibilidade e risco a escorregamentos disponível. Essa carta orientou a adoção das diretrizes de urbanização da microbacia, especialmente remoção de famílias em áreas de risco alto, estabilização de encostas e assentamentos.

Entretanto, o estudo da urbanização contemplou a legislação urbanística e ambiental e uma análise geoambiental mais completa da área ocupada, não se restringindo apenas a situações de risco a escorregamento. Dessa maneira, verificou-se a necessidade de dotar-se a área ocupada de melhores condições, em função do conhecimento de outros aspectos geoambientais da microbacia, como declividades dos terrenos, linhas de escoamento superficial e processos erosivos, que permitiram apontar outras diretrizes para o sistema viário, a drenagem superficial, sistema de água e esgoto, áreas livres e tipologias habitacionais. Além disso, foram consideradas as restrições legais ambientais como as APPs de corpos d' água e declividades.

Com essa finalidade, os diversos critérios de urbanização em encostas de altas declividades, já pesquisados e apresentados na bibliografia, foram estudados para se definir diretrizes que puderam ser aplicadas à microbacia Taquara do Reino.

Com efeito, por meio desses estudos foi possível elaborar uma alternativa de urbanização como um ensaio prático de aplicação dos critérios estudados e de valorização dos condicionantes geoambientais da microbacia Taquara do Reino, com foco principal no risco a escorregamentos.

Embora realizada como um ensaio, necessário para se praticar a aplicação do estudo realizado, a proposta é consistente com as diretrizes do Plano de Urbanização da Zona Especial de Interesse Social (ZEIS) e com o propósito da criação da APA CabuçU - Tanque Grande, como defesa das condições ambientais locais e do Parque Estadual da Cantareira, contíguo a ocupações urbanas irregulares de Guarulhos. Nesse sentido, a proposta está voltada à valorização dos serviços ambientais da Reserva da Biosfera do Cinturão Verde da Cidade de São Paulo (IF, 2006).

\section{Bibliografia}

ANDRADE, Marcio Roberto Magalhães de. Cartografia de aptidão para assentamento urbano do município de Guarulhos/SP. 1999. 154p. Dissertação (Mestrado) - Faculdade de Filosofia, Letras e Ciências Humanas, Universidade de São Paulo, São Paulo, 1999.

BRASIL. Lei n. 4771, de 15 de setembro de 1965. Institui o novo Código Florestal. Diário Oficial [da] República Federativa do Brasil, Brasília, DF, 16 set. 1965. Disponível em: <http://www.planalto.gov.br/ccivil_03/LEIS/L4771. $\mathrm{htm}>$. Acesso em: 22 maio 2006.

BRASIL. Lei n. 6.766, de 19 de dezembro de 1965. Dispõe sobre o parcelamento do solo urbano e dá outras providências. Diário Oficial [da] República Federativa do Brasil, Brasília, DF, 20 dez. 1979. Disponível em: <http://www. planalto.gov.br/ccivil_03/Leis/L6766.htm>. Acesso em: 22 nov. 2006.

BRASIL. Resolução CONAMA n. 369, de 28 de março de 2006. Dispõe sobre os casos excepcionais, de utilidade pública, interesse social ou baixo impacto ambiental, que possibilitam a intervenção ou supressão de vegetação em Área de Preservação Permanente-APP. Diário Oficial [da] República Federativa do Brasil, Brasília, DF, 29 mar. 2006. Disponível em: <http://www.cidades.gov.br/secretarias-nacionais/programas-urbanos>. Acesso em: 17 jul. 2006. 
CERRI, Leandro Eugênio da Silva; AMARAL, Claudio Palmeiro. Riscos geológicos. In: OLIVEIRA, Antonio Manoel dos Santos; BRITO, Sérgio Nertan Alves. Geologia de engenharia. São Paulo: Associação Brasileira de Geologia da Engenharia, 1998.

CUNHA, Marcio Angelieri; FARAH, Flávio; CERRI, Leandro Eugênio; GOMES, Luiz Antonio; GALVÊS, Maria Lúcia; BITAR, Omar Yazbek; AUGUSTO FILHO, Oswaldo; SILVA, Wanderley Sérgio. Manual de ocupação de encostas. São Paulo: Publicação Instituto de Pesquisas Tecnológicas, 1991.

FARAH, Flavio. Habitação e encostas. São Paulo: Publicação Instituto de Pesquisas Tecnológicas, 2003.

FIDEM - FUNDAÇÃO DE DESENVOLVIMENTO MUNICIPAL. Programa Viva o Morro em CD-ROM: texto multimídia. Recife: Ensol, 2004. 1 CD-ROM.

GOMES, Gabriela Lucia da Costa e Castro. Análise geoambiental de áreas de risco a escorregamentos nos loteamentos do Recreio São Jorge e Novo Recreio, no município de Guarulhos - SP. 2008. 97 p. Dissertação (Mestrado) - Análise Geoambiental do Centro de Pós-Graduação, Pesquisa e Extensão, Universidade Guarulhos, Guarulhos, 2008.

GUARULHOS. Lei n. 6.253, de 24 de maio de 2007. Dispõe sobre o uso, a ocupação e o parcelamento do solo no município de Guarulhos e dá providências correlatas. Diário Oficial [do] Município de Guarulhos, Guarulhos, SP, 25 mai. 2007. Disponível em: <http://www.guarulhos.sp.gov.br/06_prefeitura/leis/leis_download/06253lei.pdf> Acesso em: 30 maio 2007.

HERLING, Tereza. A floresta em São Paulo, a cidade na Cantareira: fronteiras em transformação. 2002. 222p. Tese (Doutorado) - Faculdade de Arquitetura e Urbanismo, Universidade de São Paulo, São Paulo, 2002.

IF - INSTITUTO FLORESTAL. Síntese da proposta de formação da rede sul-americana de serviços ambientais. São Paulo: Instituto Florestal, 2006. Documento interno.

LACAVA, Marco Antonio. Comportamento hídrico de superfície da bacia do rio Cabuçu de Cima, Núcleo Cabuçu do Parque Estadual da Cantareira, Guarulhos-SP. 2007. 71 p. Dissertação (Mestrado) - Análise Geoambiental do Centro de Pós-Graduação, Pesquisa e Extensão, Universidade Guarulhos, Guarulhos, 2007.

LAUTENSCHLAGER, Sandro Rogério. Modelagem no desempenho de wetlands construídas. 2001. 90p. Dissertação (Mestrado) - Escola Politécnica, Universidade de São Paulo, São Paulo. 2001.

MASCARÓ, Juan Luis. Manual de loteamentos e urbanização. 1 ed. Porto Alegre: Sagra, 1994.

MORETTI, Ricardo de Sousa Moretti. Loteamentos: manual de recomendações para elaboração de projeto. 2 ed. São Paulo: Publicação Instituto de Pesquisas Tecnológicas, 1987.

OLIVEIRA, Antonio Manoel dos Santos; ANDRADE, Marcio Roberto Magalhães de; QUEIROZ, William de; SATO, Sandra Emi. Diagnóstico ambiental para o manejo sustentável do Núcleo Cabuçu do Parque Estadual da Cantareira e áreas vizinhas do município de Guarulhos. Guarulhos: Laboratório de Geoprocessamento da Universidade GuaruIhos, 2005. Relatório Fapesp.

PMG. PREFEITURA MUNICIPAL DE GUARULHOS. Disponível em: http://www.guarulhos.sp.gov.br. Acesso em: 25 abr. 2006.

PMG. PREFEITURA MUNICIPAL DE GUARULHOS. Disponível em: http://200.182.94.4/07_noticias/lenoticia.php?id $\mathrm{Sec}=0 \& i d m e n u=0 \& o v=\& r n d=8227 \&$ idnot $=2967$. Acesso em: 12 set. 2007

QUEIROZ, William de. Impactos geoambientais da ocupação urbana na microbacia do córrego Taquara do Reino Bairro Novo Recreio, município de Guarulhos, SP. 2005. 26 p. Monografia (Especialização) - Gestão Ambiental do Centro de Pós-Graduação, Pesquisa e Extensão, Universidade Guarulhos, Guarulhos, 2005.

SATO, Sandra Emi. Estudo de urbanização em áreas de risco a escorregamentos nos loteamentos do Recreio São Jorge e Novo Recreio, região do Cabuçu, Guarulhos/SP. 2008. 68 p. Dissertação (Mestrado) - Análise Geoambiental do Centro de Pós-Graduação, Pesquisa e Extensão, Universidade Guarulhos, Guarulhos, 2008.

TUNDISI, José Galizia. Bacia hidrográfica como laboratório experimental para o ensino de ciências, geografia e educação ambiental. In: SCHIEl, Dietrich et al (EE.) O estudo de bacias hidrográficas: uma estratégia para educação ambiental. São Carlos: Rima, 2003. 